\title{
The Impact of the Green Supply Chain Management on Environmental-Based Marketing Performance
}

\author{
Suleiman A. Al Khattab ${ }^{*}$, As'ad H. Abu-Rumman², Ma'n Mustafa Massad ${ }^{2}$ \\ ${ }^{1}$ Department of Business Administration, Al Hussein Bin Talal University, Ma'an, Jordan \\ ${ }^{2}$ Department of Marketing, Applied Science Private University, Amman, Jordan \\ Email: s.alkhattab@ahu.edu.jo
}

Received 16 July 2015; accepted 11 August 2015; published 14 August 2015

Copyright (C) 2015 by authors and Scientific Research Publishing Inc.

This work is licensed under the Creative Commons Attribution International License (CC BY). http://creativecommons.org/licenses/by/4.0/

c) (i) Open Access

\section{Abstract}

This study aims to investigate “The impact of the Green Supply Chain Management” (GSCM) on Environmental-Based Marketing Performance. In order to achieve the objectives of the study, the researchers deployed the descriptive analytical approach due to its relevance to this kind of research. The sample used in this study was the stratified convenience sampling, where the study targeted the top and middle managerial levels from the population, and the targeted managerial levels was made up of (167) employees in the five companies. 125 questionnaires were distributed for the five companies with (25) questionnaires for each company. The accepted questionnaire was (96). The results of the research showed that the elements of the Green Supply Chain Management “Internal Environmental Management, Green Purchasing, Green Information Systems, Cooperation with Customers, Eco-Design and Packaging, and Investment Recovery" practices affected the environmental-based marketing performance. The results showed the element with significant impact on the environmental-based marketing performance was internal environmental management.

\section{Keywords}

Green Supply Chain Management, Marketing Performance, Nuqul Group Companies, Jordan

\section{Introduction}

Today's competitive environment, globalization and instant access to information have changed the way organ-

\footnotetext{
${ }^{*}$ Corresponding author.
}

How to cite this paper: Al Khattab, S.A., Abu-Rumman, A.H. and Massad, M.M. (2015) The Impact of the Green Supply Chain Management on Environmental-Based Marketing Performance. Journal of Service Science and Management, 8, 588597. http://dx.doi.org/10.4236/jssm.2015.84059 
izations run business and deliver products and services. These circumstances leave no options for organizations to improve their environmental performance continuously taking into consideration the marketing performance. The role of continuous improvement of environmental-based marketing within organizations has changed and matured in comparison to several decades ago.

Supply chains surrounding the companies in each different types and/or sizes and the business activities and practices are needed to be designed, made, delivered, and used for a product or service. Businesses rely on their supply chains practices to provide them with what they need to continue to thrive, working at a steady and consistent speed of change and the uncertainty about how markets will develop gradually, especially from a simple to a more complex form. It has made an increasingly of great significance or value for companies to be aware of the supply chains and its practices and managements John et al. [1]. Those companies that learn how to construct and possess strong supply chains will have considerable importance, size, worth, real and tangible market share rather than imaginary competitive advantage in their markets Pane et al. [2].

The practices of supply chains management is driven by a lot of traditions that have not changed much over the centuries. The term "supply chain management" was used in the late 1980s and became widely used in the 1990s. Prior to that time, businesses used terms such as "logistics" and "operations management" as an alternative or substitute. Lately, supply chain can be defined as "A group of inter-connected participating companies that add value to a stream of transformed inputs from their source of origin to the end products or services that are demanded by the designated end consumer” Sarkis [3].

The globalization of the supply chain also has affected how organizations manage their supply chains. Supply chain globalization requires organizations to study carefully both the cultures and policies of the source companies and their customers' situations. Organizations also have to study changing policies and norms throughout the world for thoughtful and competitive supply chains Sarkis [4].

During the end of the $19^{\text {th }}$ century and the beginning of the $20^{\text {th }}$ century, the people began the first steps of drawing a relationship between living organisms and how it related to their physical surrounding's consciousness which involved environment protection, preservation and servicing movement for the environment. This movement is born out of the need to minimize the incessant poor treatment of customers in a particular environment, bringing into frame the industrial time period and the need to utilize natural resources in a conscientious and efficient manner, by individuals and corporations alike Sarkis [4].

Nuqul Brothers Company was founded 1952. The group started their work as an import and trade company for foodstuff. Nuqul had limited operations. It has grown over the years to handle a number of financially daring projects in the Middle East region, primarily in Jordan. It has been successful, authoritative, and commanding great respect for its special importance on ethical business practices and an enthusiastic increase in monetary value for opportunity NUQULGROUP [5].

Today, Nuqul Group runs different investments and industries led by an empowered 5100 team members spanning several continents. It embodies two major holding entities; FINE Hygienic Holding (FHH) being the umbrella for paper mills, FINE hygienic paper companies and supporting industries; while The Promise Holding includes diverse investments in different sectors and modes. Table 1 classified the Nuqul Group companies in Jordan and defining the sector of each company.

One aspect of "Growing Together" means taking responsibility for using natural resources in the most effective way possible. This allows the group to continue expanding in a safer, sustainable way. Nuqul has implemented environmentally friendly technologies at their plants and mills. It makes good business sense to use resources efficiently. Waste eats profit, as well as polluting the environment; their responsibility is to leave a cleaner environment for future generations. The group feels a responsibility to address these issues now to improve the environment and to recycle and conserve whenever possible. This is their belief, and it is fast showing itself as an excellent choice. In all Nuqul's paper mills, they ensure that environmental care has been taken at all points along the production chain NUQULGROUP [5].

This research studies the tools and techniques in (GSCM), and it focuses on the following: internal environmental management, green purchasing, cooperation with customers, eco-design and packaging, and investment recovery. All of that is to enhance the issues that affect the environment. Little green suppliers are available, and the costs of resources in green suppliers are high. Those issues would be the main problems for this study. It is worthy of note that not all of the Nuqul group's firms are certified for ISO 14001 Standards, and that also some firms are certified for the ISO14001 certificate but lose their certification due to the difficulties in applying these standards. 
Table 1. Classification of Nuqul Group companies in Jordan according to its sectors.

\begin{tabular}{llcc}
\hline Nuqul Group & Sectors & Place of Company & ISO 14001 Certification \\
\hline Fine Hygienic Paper Co. Lim. & Paper Converting & Jordan & Yes \\
Al Keena Hygienic Paper Mill Co. Lim. & Paper Mills & Jordan & Yes \\
Al Snobar Paper Mill & Paper Mills & Jordan & No \\
Nuqul Engineering \& Contracting Co. & Constructions & Jordan & No \\
Perfect Printing Press Co. Lim. & Printing \& Packaging & Jordan & Yes \\
Saueressing Jordan & Printing \& Packaging & Jordan & No \\
Packaging Industries Co. Lim. & Printing \& Packaging & Jordan & No \\
Nuqul Automotive & Automotive & Jordan & No \\
Integrated Automotive & Automotive & Jordan & No \\
Quality Printing Press & Stationary & Jordan & Yes \\
Specialized Industries Co. & Others & Jordan & Yes \\
\hline
\end{tabular}

According to the above discussion, this research tries to measure the impact of Green Supply Chain Management on the Environmental-Based Marketing Performance and provide a conceptual framework that defines the importance of applying 14001 standards and its importance in the Jordanian organizations.

\section{Literature Review}

Green Supply Chain Management (GSCP) is commonly used in literatures when we want to spot on the differences of activities done by the organizations in order to minimize their environmental and natural impact Sarkis et al. [6]. The circumstances of GSCMP, collaboration between the organizations is much more important for all of management's practices, coordination and cooperation between the internal and external managements should be prober well to have the successful system implementation throughout the whole of all the supply chain channels Zhu et al. [7]. Supplier management in GSCs, or green supplier management, has captured significant interest in the current literature Lee et al. [8]; Kim and Min [9]. In the past decades, firms moved their production facilities and business departments offshore to benefit from lower production and service costs. The wide view of sustainability revolves around of economic, social, and environmental performance. The risks and challenges that occur along the entire global supply chains and the new extended supply chains hide a number of potential risks as well. Such unresolved issues as product quality, inventory control, lead time, and buyersupplier trust could be amplified by new risk factors-distance, language, and cultural diversity besides supply chain disruption by natural disasters Pane et al. [2]. Due to the distance and cultural diversity, it is challenging for the focal firms to develop and execute integrated strategic, tactical and operational manufacturing, as well as distribution plans of plants scattered over the world Sarkis [3]. Firms can obtain sustainable competitive advantage and improved organizational performance Zailani et al. [10]. Supply chains strive to maintain internal health and environmental sustainability using the capability to self-correct based on information from the external environment Kenneth and Green [11]. There is a common three step supplier management portfolio model: analysis of the products and their classification; analysis of the supplier relationships required delivering the products; and action plans in order to match the product requirements with the supplier relationships.

\section{Elements of Supply Chain Management}

Internal environmental management: Practices (SCM components) adopted are a function of external (open system view of organization) and internal environment (management component). Internal organizational supply chain activities are related to traditional production and operations management topics of an organization.

Also, stress the need to examine internal factors (IF) as well as external environmental factors driving green logistics is highly recommended. Within an organization, pressure from employees, leadership from environmentally committed management and perception of possible environmental risk might all contribute to changes in environmental practices in organizations Harrison [12]. 
It is difficult to define which of this range within an organization influences GSCM initiatives and their relative success. There is consensus within the literature that internal environmental management is a key to improving enterprises' performance Hanna et al. [13].

It is well known that senior managers' support is necessary and, often, a key driver for successful adoption and implementation of most innovations, technology, programs and activities. To ensure complete environmental excellence, top management must be totally committed Al Khattab [14].

Green information systems: With the huge amount of growth in technology and the ease in collecting data and using the internet, but it still there are limits of forms of available information and also on the proprietary aspects (security, competitive advantage, etc.) aspects of information. Virtual boundaries may exist in the sharing of information, but also there are issues of the actual availability of information, where no easily accessed information may exist after a certain point in the supply chain Sarkis [3]. The available information is more difficult to collect while trying to study the suppliers to maintain if the supplier is using a green management system or not Lee [15]. Organizations have to be aware of the environmental implications of their processes and also have to maintain the operations of their suppliers and the processes of them.

Green purchasing: Purchasing function activities center on the acquisition of materials from suppliers to meet the needs of producing the organizational product or service. Purchasing includes specific responsibilities such as vendor selection, material selection, outsourcing, negotiation, buying, delivery scheduling, inventory and materials management, and to some extent, involvement in design. As organizations tend to focus on outsourcing non-core competency activities, the role of the purchasing function becomes more important and strategic, and thus the greater influence of supply chain management Michael [16].

One of the most important functions of green purchasing and supplier management is supplier selection. Research in "general supplier selection" is particularly important as organizations have increasingly focused on developing their core competence and outsourcing less profitable activities to supply chain partners. This evolution resulted in a more strategic focus on the buyer-supplier relationship where close collaboration was necessary and certain skills and capabilities were required Sarkis et al. [6].

Cooperation with customers: A cooperative supply chain leads to coordinate its partnerships to produce and distribute commodities and services along the chain, for minimum overall costs. This is geared towards satisfying the customers' demands. A combined multi-period, multiple products and multiple stages in supply chain is created or devised methodically using a flow networks supporting structure of the objectives of the customers' needs.

The importance of having such an understanding cannot be over-exaggerated when taking the conceder of greening the environment for more sustainability for strategic portions of managements' processes. For example, the high-level of knowledge should be integrated well to help reducing uncertainty and the risk associated with the processes and activities that affect the environment in deep Al Khattab [14]. The cost reduction is the basic or inherent feature of environmental improvement which leads the organizations to be more able to satisfy customer demands for more sustainable environment's products absolute in environmental performance should lead to overall improvement in the both fields; marketing performance and financial performance for the organization.

Eco-design \& Packaging: Design for Environment (DfE) or Eco-design refers to environmental design of a product and/or a process. It focuses on reducing (preventing) the environmental effects of a product before it is produced, distributed and used. DfE examines the disassembly of products at the end-of-life and reveals the associated cost benefits and environmental impact of revision, reuse and recycling Harrison [12]. DfE has its origins in the concepts of concurrent engineering and design for manufacturability and assembly (DFMA). Concurrent engineering, also defined as simultaneous engineering, is the practice by management and operations of designing products and processes by multi-functional teams throughout a product's life cycle from idea generation, design, development, manufacturing, service, maintenance and disposal. Closely related to this principle is DFMA, where DFMA is defined the process of proactively designing products to 1) optimize all the manufacturing functions: fabrication, assembly, test, procurement, shipping, delivery, service, and repair, and 2) assure the best cost, quality, reliability, regulatory compliance, safety, time-to-market, and customer satisfaction. The major goals of these programs is to simplify product designs so that they could be made inexpensively over the full product's life cycle, but also considered the other elements of product and process control. The DfE process usually entails five major steps:

1) Assess environmental impacts. 
2) Research the market.

3) Run an ideas workshop (brainstorm), or ideas generation.

4) Select design strategies.

5) Design the product.

Investment recovery: Effective and efficient control of the purchasing and handling of materials can significantly reduce waste generation. Inventory control is meant to minimize costs and appropriate planning will help minimize the amount of materials and products that are lost due to a variety of inventory reasons including obsolescence, spoilage and losing products. There are issues with managing the control and various lean principles (JIT and lean manufacturing philosophies) may help to more effectively manage in these environments MingKuei [17]. Material remaining after the product has expired will require disposal. Companies should store materials in a locked space and limit access to a few designated employees. By controlling access to raw materials, operators will ensure that containers are completely empty before new containers are opened.

Management should establish standard operating procedures for inventory control and purchasing, working with suppliers to take back empty or off-spec containers. Inventory appears throughout the supply chain, including inside an organization and through the logistics network. Efficient inventory planning and management does not only help to decrease solid wastes, but also decrease air emissions such as greenhouse gas emissions.

Information technology in inventory management plays a crucial role in improving control of the inventory and maintaining a greater positive environmental influence. This issue relates to the discussion on having appropriate enterprise resource planning systems. In fact, it has been found that for organizations that there is a correlation between those organizations that have lessened inventory and good environmental performance Al Khattab and Fraij [18].

Environmental-Based Marketing Performance: It is a term used by marketing professionals to describe the analysis and improvement of the efficiency and effectiveness of marketing. This is accomplished by focusing on the alignment of marketing activities and strategies. The ability of manufacturing plants to reduce air emissions, effluent waste, and solid wastes and the ability to decrease consumption of hazardous and toxic materials Zhu et al. [7]. The focus of environmental management has moved from the organization level to the supply chain level Lo and Leung [19]; Kenneth et al. [11]. Shi et al. [20] defined an environmental supply chain management as the managerial integration of materials and information flow throughout the supply chain to satisfy the demand of customers for green products and services produced by green processes. The discussion in this research described the many practices, technologies, and concerns in GSCM. The complexities of both supply chain management and corporate environmental management practices are a great barrier, alone, for their implementation. When they are joined together to form GSCM, the complexities, effort, and costs, can increase exponentially.

The impact of green supply chain management and its practices it shall lead to affects not only on the environmental-based marketing performance, it also affects other portions of marketing performances. Most of researchers wrote about the impact of the GSCMP on the Marketing performance, they are listed below:

- Environmental Performance.

- Economic Performance.

- Operational Performance.

- Organizational Performance.

It's known that the marketing performance may be included in all of these performances' portions.

According to the above discussion the GSCM's tools as independent variables and the Environmental-based Marketing Performance as dependent variable can be seen in the research model (Figure 1) as below.

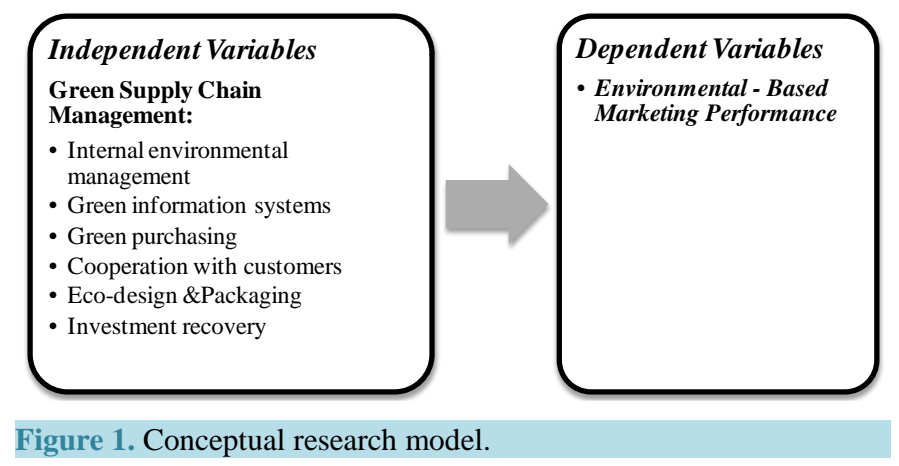


In accordance with the study objectives and consistent with the related literature, the following main and suphypotheses have been tested:

Ho.1: There is no impact of overall dimensions of Green Supply Chain Management on the environmental-based marketing performance.

The sub-hypotheses are:

- Ho.1.1: There is no impact of Internal Environmental Management on the environmental-based marketing performance.

- Ho.1.2: There is no impact of Green Information Systems on the environmental-based marketing performance.

- Ho.1.3: There is no impact of Green Purchasing on the environmental-based marketing performance.

- Ho.1.4: There is no impact of Cooperation with Customers on the environmental-based marketing performance.

- Ho.1.5: There is no impact of Eco-Design and Packaging on the environmental-based marketing performance.

- Ho.1.6: There is no impact of Investment Recovery on the environmental-based marketing performance.

\section{Research Methodology}

\subsection{Population and Sample of the Study}

The study population consists of Nuqul Group companies in Jordan applying the Environmental Management System ISO 14001, whether their size is small, medium or large organisation. The certified ISO14001 Nuqul group's companies in Jordan total of (643) employees in all of them together. The population of study is represented by the employees who are working in the organization from each department drawn from both middle and top managements. The study focused on the employees who are participating in the environmental-marketing performance and all of the departments in the population were involved in, because of their capabilities in diagnosing the study variables.

The sample that is used in this study is the stratified convenience sampling, where the study targeted the top and middle managerial levels from the population, and the targeted managerial levels are contains (167) employees in the five companies together. 125 questionnaires have been distributed for the five companies targeted with (25) questionnaires for each company. The accepted questionnaire was (96) questionnaires. Table 2 shows the responses for distributing the questionnaires.

Table 2. Description of the questionnaire responses.

\begin{tabular}{cccc}
\hline Company Name & No. of distributed Questionnaires & No. of Accepted Questionnaires & Frequency Percentage \\
\hline Fine Jo & 25 & 20 & 20.8 \\
QPP & 25 & 17 & 17.7 \\
PPP & 25 & 22 & 22.9 \\
Al-Keena & 25 & 19 & 19.8 \\
SPIC & 25 & 18 & 18.8 \\
Total & 125 & 96 & 100.0 \\
\hline
\end{tabular}

\subsection{Study Instrument}

The questionnaire was developed to collect data from the sample of the study after reviewing some of the previous literature addressing each of the variables examined in the study, it contains three domains of questions, the first group is about demographic questions (gender, position, experience, academic qualifications, and the name of the company), second group is about green supply chain management practices which includes six sub domains and was covered by (28) questions Sarkis [3], Kenneth et al. [11], Shi et al. [20], Björklund and Abrahamsson [21] Lee [15], third group about environmental-based marketing performance and was covered by (6) questions Zhu et al. [7]; Shi et al. [20]. 


\subsection{Reliability}

To declare the sincerity of the survey variables for the phenomenon being studied, the researcher used the reliability test which indicates to the extent of reliance on the measurement tool in giving the same results.

The researcher used Cronbach Alpha to test the answers and Table 3 shows that:

Table 3. Reliability test using Cronbach Alpha.

\begin{tabular}{ccc}
\hline Variables & No of Items & Cronbach Alpha \\
GSCM & 28 & 0.788 \\
Internal Environmental Management & 6 & 0.758 \\
Green Information Systems & 5 & 0.836 \\
Green Purchasing & 5 & 0.901 \\
Cooperation with Customers & 5 & 0.906 \\
Eco-Design \& Packaging & 4 & 0.775 \\
Investment Recovery & 3 & 0.911 \\
All Variables & 6 & 34 \\
\hline
\end{tabular}

\section{Data Analysis and Hypotheses Testing}

\subsection{Sampling Characteristics}

The sample was described by personal and functional factors based on the respondent's characteristics from Nuqul group companies in Jordan applying ISO 14001 standards as shown in Table 4.

Table 4. The frequencies and percentages of the personal levels of the respondents.

\begin{tabular}{|c|c|c|c|}
\hline \multicolumn{2}{|c|}{ Personal factors } & \multirow{2}{*}{$\begin{array}{c}\text { Frequency } \\
56\end{array}$} & \multirow{2}{*}{$\begin{array}{c}\text { Percen } \\
58.3\end{array}$} \\
\hline & Male & & \\
\hline 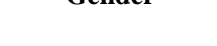 & Female & 40 & 41.7 \\
\hline \multirow{2}{*}{ Managerial level } & Upper management & 51 & 53.1 \\
\hline & Middle management & 45 & 46.9 \\
\hline \multirow{5}{*}{ Experience } & 5 years or less & 5 & 5.2 \\
\hline & $5-9$ & 25 & 26.0 \\
\hline & $10-14$ & 45 & 46.9 \\
\hline & $15-19$ & 9 & 9.4 \\
\hline & More than 19 & 12 & 12.5 \\
\hline \multirow{3}{*}{ Education level } & Diploma & 0 & 0 \\
\hline & Bachelor & 56 & 58.3 \\
\hline & Graduate studies & 40 & 41.7 \\
\hline \multirow{5}{*}{ Company name } & Fine Jo & 20 & 20.8 \\
\hline & QPP & 17 & 17.7 \\
\hline & PPP & 22 & 22.9 \\
\hline & Al-Keena & 19 & 19.8 \\
\hline & SPIC & 18 & 18.8 \\
\hline
\end{tabular}




\subsection{Description of Study Variables}

Descriptive statistics, the researcher computed the means and standard deviations for all the study domains as shown in Table 5:

Table 5. Means and standard deviations for the study main domains.

\begin{tabular}{cccc}
\hline Item & Mean & Std. deviation & Agreement degree \\
\hline Internal environmental management & 4.722 & 0.24503 & High \\
Green information systems & 4.552 & 0.399 & High \\
Green purchasing & 4.635 & 0.338 & High \\
Cooperation with customers & 4.734 & 0.287 & High \\
Eco-design \& packaging & 4.556 & 0.475 & High \\
Investment recovery & 4.661 & 0.238 & High \\
Environmental-based marketing performance & 4.754 & 0.250 & High \\
\hline
\end{tabular}

From the previous Table 5, the mean for the domains were from (4.55) to (4.76) referring to a degree of agreement, where the Environmental-based Marketing Performance got the highest mean (4.754) and standard deviation (0.250), also the domain Green information systems with mean (4.552) and standard deviation (0.399), at the last rank.

\subsection{Testing the Study Hypotheses}

Ho.1: There is no impact of overall dimensions of Green Supply Chain Management on the environmentalbased marketing performance.

Simple regression was performed and the results in Table 6 showed that the strength of the relation between the overall dimensions of green supply chain management practices and environmental-based marketing performance was $(\mathrm{R}=59.7 \%)$, and the coefficient of determination $\left(\mathrm{R}^{2}=0.356\right)$ which is an acceptable percentage, meaning that $(35.6 \%)$ of the total differences in the environmental-based marketing performance is determined through the GSCM, and the remaining percentage is equal to (64.4\%) representing contribution percentage of the excluded variables that were not included in the study model. The value of computed $(\mathrm{F}=51.932)$ which is higher than the tabular F at degree of freedom $(1-120)$ at significance level of $(0.000)$, this indicates that the curve of regression is good in explaining the relation between the green supply chain management practices and the environmental-based marketing performance.

Table 6. The impact of overall GSCMP on environmental-based marketing performance.

\begin{tabular}{cccc}
\hline Independent variable & $\boldsymbol{\beta}$ & $\boldsymbol{T}$ & Sig \\
\hline GSCM & 0.597 & 7.206 & 0.000 \\
\hline
\end{tabular}

$\left(\mathrm{R}=0.597 ; \mathrm{R}^{2}=0.356 ; \mathrm{F}=51.932\right) ;{ }^{*}$ significant level at $\mathrm{P} \leq 0.05$.

The results of the simple regression analysis showed that there is significant impact of the overall GSCM practices on the environmental-based marketing performance, $(\beta=0.597)$ at level of significance $(0.000)$. Accordingly we reject the null hypothesis and accept the alternative hypothesis.

Sub-Hypotheses:

From Table 7, the results of the analysis showed that there is significant impact of the internal environmental management on the environmental-based marketing performance, $(\beta=0.288)$ at level of significance (0.036).

The results of the analysis showed that there is significant impact of the green information systems on the environmental-based marketing performance, $(\beta=0.250)$ at level of significance $(0.013)$.

The results of the analysis showed that there is significant impact of the green purchasing on the environmental-based marketing performance, $(\beta=0.445)$ at level of significance $(0.006)$.

The results of the analysis showed that there is significant impact of the cooperation with customers on the 
Table 7. The impact of GSCM’s elements on environmental-based marketing performance.

\begin{tabular}{cccc}
\hline Independent variable & $\boldsymbol{\beta}$ & $\boldsymbol{T}$ & Sig \\
\hline Internal environmental management & 0.288 & 2.134 & $0.036^{*}$ \\
Green information systems & 0.250 & 2.541 & $0.013^{*}$ \\
Green purchasing & 0.445 & 2.804 & $0.006^{*}$ \\
Cooperation with customers & 0.352 & 3.557 & $0.001^{*}$ \\
Eco-design and packaging & 0.293 & 3.164 & $0.002^{*}$ \\
Investment recovery & 0.244 & 2.682 & $0.009^{*}$ \\
\hline
\end{tabular}

$\left(\mathrm{R}=0.749 ; \mathrm{R}^{2}=0.561 ; \mathrm{F}=49.783\right) ;{ }^{*}$ significant level at $\mathrm{P} \leq 0.05$.

environmental-based marketing performance, $(\beta=0.352)$ at level of significance $(0.001)$.

The results of the analysis showed that there is significant impact of the eco-design and packaging_on the environmental-based marketing performance, $(\beta=0.293)$ at level of significance $(0.002)$.

The results of the analysis showed that there is significant impact of the investment recovery on the environmental-based marketing performance, $(\beta=0.244)$ at level of significance $(0.009)$.

\section{Findings and Discussion}

This study investigated the elements of the Green Supply Chain Management (GSCM) "Internal Environmental Management, Green Purchasing, Green Information Systems, Cooperation with Customers, Eco-Design and Packaging, and Investment Recovery” and its impact on the environmental-based marketing performance . The results of the research showed that each of the studied factors or practices of the Green Supply Chain Management practices affect the environmental-based marketing performance.

In more details, the results of the analysis showed that there is significant impact of the internal environmental management on the environmental-based marketing performance where $(\beta=0.288)$ at level of significance (0.036). By analyzing the results of green information systems domain it shows that there is significant impact of the green information systems on the environmental-based marketing performance where $(\beta=0.250)$ at level of significance (0.013), which is consistent with Lee et al. [8], Sarkis [4], Zhu et al. [7]. The analysis of green purchasing portion shows the significant impact of the green purchasing on the environmental-based marketing performance where $(\beta=0.445)$ at level of significance (0.006), which is consistent with Lee [15]; Kim and Min [9]; Zhu et al. [7]. The results of the analysis showed that there is significant impact of the cooperation with customers on the environmental-based marketing performance where $(\beta=0.352)$ at level of significance $(0.001)$, which also matches the results of Holt and Ghobadinan [22], Zailani et al. [10]. The analysis showed that there is significant impact of the eco-design and packaging on the environmental-based marketing performance where ( $\beta=0.293)$ at level of significance (0.002), which is consistent with Hanna et al. [13], Sarkis [4]. By analyzing the results of investment recovery domain it shows that there is significant impact of the investment recovery on the environmental-based marketing performance where $(\beta=0.244)$ at level of significance $(0.009)$, which is consistent with Sarkis et al. [6].

\section{Limitations of the Study and Suggestions for Further Work}

The study has a few limitations which should be considered when interpreting its results, and these naturally form the basis of suggestions for future research. One limitation is that the data are collected from Nuqul Group Companies in Jordan, and hence, the findings may not be generalizable to other contexts. A direction for future research would be to replicate this study in other sectors. The study can be replicated in different cultures to provide cross-cultural comparisons, and to take account of both customers and managers viewpoints.

\section{References}

[1] John, W., Steve, D. and Howard, F. (2012) A Study on Green Supply Chain Management Practices among Large Global Corporations. Journal of Supply Chain and Operations Management, 10. 
[2] Pane, H., Oyler, J. and Humphreys, J. (2009) Historical, Practical, and Theoretical Perspectives on Green Management. Management Decision, 47, 1041-1055. http://dx.doi.org/10.1108/00251740910978287

[3] Sarkis, J. (2014) Green Supply Chain Management. ASME, New York.

[4] Sarkis, J. (2012) A Boundaries and Flows Perspective of Green Supply Chain Management. Supply Chain Management: An International Journal, 17, 202-216. http://dx.doi.org/10.1108/13598541211212924

[5] NUQUL Group (2014) www.nuqulgroup.com

[6] Sarkis, J., Hervani, A. and Helms, M. (2005) Performance Measurement for Green Supply Chain Management. Benchmarking: An International Journal, 12, 330-353.

[7] Zhu, Q., Dou, Y. and Sarkis, J. (2010) A Portfolio-Based Analysis for Green Supplier Management Using the Analytical Network Process. Supply Chain Management: An International Journal, 15, 306-319. http://dx.doi.org/10.1108/13598541080001414

[8] Lee, S. Kim, S.T. and Choi, D. (2012) Green Supply Chain Management and Organizational Performance. Industrial Management \& Data Systems, 112, 1148-1180. http://dx.doi.org/10.1108/02635571211264609

[9] Kim, I. and Min, H. (2009) Measuring Supply Chain Efficiency from a Green Perspective. Management Research Review, 34, 1169-1189.

[10] Zailani, S., Eltayeb, T., Hsu, C. and Tan, K. (2012) The Impact of External Institutional Drivers And Internal Strategy on Environmental Performance. International Journal of Operations \& Production Management, 32, 721-745. http://dx.doi.org/10.1108/01443571211230943

[11] Kenneth, W., Green, J., Zelbst, P.J., Bhadauria, V.S. and Meacham, J. (2012) Do Environmental Collaboration and Monitoring Enhance Organizational Performance? Industrial Management \& Data Systems, 112, 186-205. http://dx.doi.org/10.1108/02635571211204254

[12] Harrison, V. (2011) Logistic Management and Strategy: Competing through the Supply Chain. Prentice Hall, London.

[13] Hanna, J.B., Hazen, B.T. and Cegielski, C. (2011) Diffusion of Green Supply Chain Management Examining Perceived Quality of Green Reverse Logistics. The International Journal of Logistics Management, 22, 373-389. http://dx.doi.org/10.1108/09574091111181372

[14] Al Khattab, S. (2012) Marketing Strategic Alliances: The Hotel Sector in Jordan. International Journal of Business and Management, 7, 222-232. http://dx.doi.org/10.5539/ijbm.v7n9p222

[15] Lee, K. (2009) Why and How to Adopt Green Management into Business Organizations? The Case Study of Korean SMEs in Manufacturing Industry. Management Decision, 47, 1101-1121. http://dx.doi.org/10.1108/00251740910978322

[16] Hugos, M. (2011) Essentials of Supply Chain Management. Wiley, Hoboken.

[17] Ming-Kuei, C. (2014) Influences of Green Supply Chain Management Practices on Organizational Sustainable Performance. International Journal of Environmental Monitoring and Protection, 1, 12-23.

[18] Al Khattab, S. and Fraij, F. (2011) Assessing Students' Satisfaction with Quality of Service of Students Information System. Management and Marketing Journal, IX, 111-225.

[19] Lo, C. and Leung, S. (2000) Environmental Agency and Public Opinion in Guangzhou: The Limits of a Popular Approach to Environmental Governance. The China Quarterly, 163, 677-704. http://dx.doi.org/10.1017/s0305741000014612

[20] Shi, V., Lenny Koh, S., Baldwin, J. and Cucchiella, F. (2012) Natural Resource Based Green Supply Chain Management. Supply Chain Management: An International Journal, 17, 54-67. http://dx.doi.org/10.1108/13598541211212203

[21] Björklund, M. and Abrahamsson, M. (2012) Performance Measurements in the Greening of Supply Chains. Supply Chain Management: An International Journal, 17, 29-39. http://dx.doi.org/10.1108/13598541211212186

[22] Holt, D. and Ghobadian, A. (2009) An Empirical Study of Green Supply Chain Management Practices Amongst UK Manufacturers. Journal of Manufacturing Technology Management, 20, 933-956. http://dx.doi.org/10.1108/17410380910984212 